\title{
Market Orientation for Better Accountability of Government-Linked Companies
}

\author{
Jamaliah Said \\ Accounting Research Institute \\ Universiti Teknologi MARA, Shah Alam \\ Selangor, Malaysia \\ E-mail: jamaliah533@ salam.uitm.edu.my
}

Md. Mahmudul Alam

School of Economics, Finance \& Banking, College of Business

Universiti Utara Malaysia

Sintok, Kedah, Malaysia

E-mail: rony000@gmail.com

\author{
Nik Herda Abdullah \\ Faculty of Accountancy \\ Universiti Teknologi MARA, Shah Alam \\ Selangor, Malaysia \\ E-mail: nik_herda@yahoo.com \\ Nur Nadiah Zulkarnain \\ Faculty of Accountancy \\ Universiti Teknologi MARA, Shah Alam \\ Selangor, Malaysia
}

\section{Citation Reference:}

Said, J., Alam, M.M., Abdullah, N.H.N. and Zulkarnain, N.N. 2016. Market Orientation for Better Accountability of Government-Linked Companies. Malaysian Accounting Review, 15(1): 287-295. Available at: http://arionline.uitm.edu.my/ojs/index.php/MAR/article/view/573

This is a pre-publication copy.

The published article is copyrighted by the publisher of the journal. 


\title{
Market Orientation for Better Accountability of Government-Linked Companies
}

\begin{abstract}
This study assesses the status of the current level of market orientation among the Government-Linked Companies (GLCs) in Malaysia. This study collected primary data based on a set of questionnaire survey among 134 executives and managers of GLCs in Malaysia. The data were collected based on opinions of the ten factors of market orientation practices by using the five-point Likert scale. The data were analysed using descriptive statistics. On an average, $86.6 \%$ of the respondents agreed that they focus on these factors of market orientation. The federal owned GLCs place more emphasis on market orientation than the state owned GLCs. This study suggests improving the practices of market orientation of GLCs in Malaysia by emphasizing on providing close attention to after-sales service, responding rapidly to the threats of competitive actions, regularly discussing the competitors' strengths and strategies by top management, and freely communicating successful and unsuccessful customer experiences across all business functions. It is suggested that Malaysian GLCs should serious invest in market orientation to deliver higher accountability outcomes.
\end{abstract}

Key Words: market orientation, accountability, government-linked companies, sustainable competitive advantage, Malaysia

\section{Introduction}

In Malaysia the government owns at least twenty percent of paid up capital in the Government Linked Companies (GLCs). Therefore it is expected that GLCs are actively involved in market orientation to ensure better accountability. Market orientation can bring many advantages, as it is a powerful source for the organization to achieve superior performance and create value for the organization (Gupta \& Benson, 2011). According to Barney (1991), organizations could create competitive advantages by obtaining valuable, rare, inimitable resources, and capabilities. Obtaining such resources will lead to value creation and sustainability in the organization. Kraaijenbrink \& Spender (2011) also state that without value creation, the organization would have no added value and thus, there would be no reason for the organization to exist in the market. Value creation can improve the performance of the organization by maximizing earnings per share, ensure high levels of operational effectiveness, and remain competitive (Gholami, 2011). This will indirectly help the organization to implement strategies to improve their efficiency and competitiveness (Porter, 1997). However, there is no guarantee that all of the resources will lead to competitive advantage or value creation. This is because, according to Kraaijenbrink and Spender (2011), people may perceive values differently.

In order to ensure the sustainability of some government agencies, the government of Malaysia decided to privatize the companies, which led to the formation of the GovernmentLinked Companies (GLCs). GLCs are defined as companies that achieve the primary commercial objective of the Malaysian government (Khazanah, 2014) and the Malaysian government has a direct controlling stake in these companies (OECD, 2013). The controlling stake refers not only to the percentage of their ownership, but also their direct or indirect influence in the appointment of directors and senior management officers. They also make 
major decisions such as contracting awards, strategizing, restructuring, financing, and acquisition and divestments through Government-Linked Investment Companies (GLICs). However, past studies still show that GLCs lack value creation compared to non-GLCs (Entebang, 2010; Razak et al., 2011). Muslim, Hafiz, and Fekri Ali (2012) state that GLCs have suffered from recurring poor firm performances due to the lack of value creation in their organization, which has made them come under the government's scrutiny. Razak et al. (2011) find that non-GLCs' performances are better than GLCs in terms of their corporate governance and other forms of specific characteristics, which makes them create more value than GLCs. This is because GLCs do not focus too much on maximizing profits, as they are also concerned about contributing towards nation building (Lau \& Tong, 2008).

Several GLCs are unable to create value and thus suffer from poor performances such as the Malaysian Airline System (MAS) and Proton Holding Berhad. Hence, GLCs need to put in extra initiatives to create value so that they will be able to meet the requirements and expectations of the government and at the same time, be able to increase and add value to their products, services, and business performance (Lawler \& Mohrman, 2013). Khazanah (2014) states that GLCs are expected to improve and enhance their value creation by focusing on sustainable practices and execution from 2015 onwards. Currently, GLCs, especially the G20 ${ }^{1}$ companies, have started to focus on sustainable practices to achieve long-term value creation. However, some GLCs tend to undermine the importance of sustainable practices as they have several goals to accomplish. Moreover, there are currently limited researches done on value creation in Malaysian GLCs (Lau \& Tong, 2008). Under this circumstance, this study investigates the practices of sustainable competitive advantage strategies among different categories of Government-Linked Companies (GLCs) in Malaysia. Market orientation is one of the ways for organizations to enhance their value creation and obtain competitive advantage (Arumugam, Guptan, \& Sganmugam, 2011).

Companies, especially GLCs, can also be sustained by understanding their market and environment (Fang et al., 2014). Market orientation is important to GLCs, as it will reflect the companies' actions towards the satisfaction of customers, competitors, and others (Boso, Story, \& Cadogan, 2013). This will enable the organization to attract and retain new and existing customers. Fang et al. (2014) propose that organizations need to have sufficient resources and market knowledge in order to sustain in the market. Thus, by gaining sufficient knowledge of the market, GLCs will be able to create value, as they will be able to act rationally towards any changes in the market. Therefore, this study investigates the practices of market orientation as a strategy of sustainable competitive advantage among different categories of Government-Linked Companies (GLCs) in Malaysia.

\section{Methodology}

\subsection{Sampling and Data Collection}

The data for this study are collected based on a questionnaire survey among 134 executives and managers of GLCs in Malaysia. The survey was conducted between February and April of 2015 .

\subsection{Measurements of Variables}

\footnotetext{
${ }^{1}$ G20 is the selection of large GLCs, which are controlled by GLICs under the GLCT Programme and is used as a proxy for performance of the GLCs. However, the G20 currently consists of only 17GLCs due to mergers, demergers, divestments, and other corporate exercises over the years.
} 
This study uses ten parameters to measure the practices of market orientation adopted from McLaughlin (2002). Market orientation is measured based on its behavioral components, which include customer orientation, competitor orientation, and inter-functional coordination. The respondents are asked to compare all the practices of innovation in their organization against their competitors in the same industry for at least three years. The questionnaire uses a five-point Likert rating scale ranging from 1 (strongly disagree) to 5 (strongly agree).

\section{Analysis and Finding}

The study measures the practices of market orientation in GLCs using ten variables. Among the respondents, on an average, $86.6 \%$ agree that they exercise these factors of market orientation and $1.5 \%$ mention that they do not practise them (Table 2).

Table 2: Score of the factors of market orientation among the GLCs in Malaysia

\begin{tabular}{|c|c|c|c|c|c|c|c|c|c|c|c|}
\hline Score & 01 & $\mathbf{O 2}$ & $\mathbf{O 3}$ & O4 & 05 & 06 & $\mathbf{O 7}$ & $\mathbf{O 8}$ & O9 & 010 & $\begin{array}{c}\text { All } \\
\text { Average }\end{array}$ \\
\hline 1 & 1 & 1 & 1 & 1 & 3 & 2 & 0 & 0 & 2 & 0 & 0 \\
\hline 2 & 2 & 1 & 1 & 7 & 6 & 5 & 4 & 6 & 5 & 6 & 2 \\
\hline 3 & 16 & 18 & 16 & 30 & 23 & 26 & 26 & 21 & 30 & 18 & 16 \\
\hline 4 & 69 & 73 & 68 & 52 & 72 & 63 & 69 & 72 & 67 & 70 & 82 \\
\hline 5 & 46 & 41 & 48 & 44 & 30 & 38 & 35 & 35 & 30 & 40 & 34 \\
\hline Disagree (1-2) & 3 & 2 & 2 & 8 & 9 & 7 & 4 & 6 & 7 & 6 & 2 \\
\hline Agree (4-5) & 115 & 114 & 116 & 96 & 102 & 101 & 104 & 107 & 97 & 110 & 116 \\
\hline Disagree $\%(1-2)$ & $2.2 \%$ & $1.5 \%$ & $1.5 \%$ & $6.0 \%$ & $6.7 \%$ & $5.2 \%$ & $3.0 \%$ & $4.5 \%$ & $5.2 \%$ & $4.5 \%$ & $1.5 \%$ \\
\hline Agree\% (4-5) & $85.8 \%$ & $85.1 \%$ & $86.6 \%$ & $71.6 \%$ & $76.1 \%$ & $75.4 \%$ & $77.6 \%$ & $79.9 \%$ & $72.4 \%$ & $82.1 \%$ & $86.6 \%$ \\
\hline Average & 4.17 & 4.13 & 4.20 & 3.98 & 3.90 & 3.97 & 4.01 & 4.01 & 3.88 & 4.07 & 4.10 \\
\hline Maximum & 1 & 1 & 1 & 1 & 1 & 1 & 2 & 2 & 1 & 2 & 2 \\
\hline Minimum & 5 & 5 & 5 & 5 & 5 & 5 & 5 & 5 & 5 & 5 & 5 \\
\hline Std. Dev. & 0.75 & 0.72 & 0.73 & 0.91 & 0.88 & 0.88 & 0.76 & 0.78 & 0.85 & 0.78 & 0.65 \\
\hline Factor Loading & 0.78 & 0.77 & 0.77 & 0.75 & 0.75 & 0.74 & 0.74 & 0.74 & 0.72 & 0.62 & \\
\hline
\end{tabular}

Among all the factors of market orientation, the highest mean score is 4.2 for the factor of business driven beliefs on how to create greater value for customers $(\mathrm{O} 3)$, and the lowest mean score is 3.88 for the factor of free communication about successful and unsuccessful customer experiences across all business functions (O9) (Table 2). The average mean value is 4.1 . There is scope to improve the overall market orientation by emphasizing the factors that are far below the average score such as providing close attention to after-sales service (O4), responding rapidly to the threats of competitive actions (O5), regularly discussing competitors' strengths and strategies by top management (O6), and free communication about successful and unsuccessful customer experiences across all business functions (O9).

Table 3: Score of the factors of market orientation according to the types of GLCs in Malaysia

\begin{tabular}{ccccccccccccc}
\hline \multicolumn{2}{c}{ Category } & O1 & O2 & O3 & O4 & O5 & O6 & O7 & O8 & O9 & O10 & Total \\
\hline GLC & State & 3.90 & 3.95 & 3.93 & 3.73 & 3.73 & 3.78 & 3.73 & 3.70 & 3.58 & 3.83 & 3.78 \\
Type & Federal & 4.27 & 4.20 & 4.31 & 4.07 & 3.93 & 4.03 & 4.10 & 4.15 & 4.01 & 4.19 & 4.13 \\
& Other & 4.50 & 4.38 & 4.38 & 4.25 & 4.38 & 4.25 & 4.38 & 4.13 & 4.00 & 4.13 & 4.28 \\
Industry & Service & 4.28 & 4.11 & 4.13 & 4.08 & 3.89 & 3.92 & 4.15 & 4.13 & 3.89 & 4.19 & 4.08 \\
Type & Manufacturing & 4.00 & 4.08 & 4.38 & 4.15 & 3.77 & 3.69 & 3.77 & 4.00 & 4.08 & 4.08 & 4.00 \\
& Other & 4.12 & 4.16 & 4.22 & 3.87 & 3.93 & 4.06 & 3.94 & 3.93 & 3.84 & 3.99 & 4.00 \\
\hline
\end{tabular}


Overall, the federal owned GLCs place more emphasis on the factors of market orientation than the state owned GLCs (Table 3). Among the factors of market orientation, the state owned GLCs emphasize the most on the strategy for competitive advantage based on understanding customer needs (O2) and emphasize the least on free communication about successful and unsuccessful customer experiences across all business functions (O9). On the other hand, the federal owned GLCs place the most emphasis on the factor of business driven beliefs on how to create greater value for customers (O3) and the least emphasis on the factor of responding rapidly to the threats of competitive actions (O5).

The GLCs engaged in the service sector are more focused on organizational learning than other sectors (Table 3). These service sector GLCs emphasize the most on monitoring the level of commitment and orientation in serving the customers' needs $(\mathrm{O} 1)$ and emphasize the least on the factor of responding rapidly to the threats of competitive actions (O5), and free communication about successful and unsuccessful customer experiences across all business functions (O9). The GLCs engaged in the manufacturing sector place the most emphasis on the factor of business driven beliefs on how to create greater value for customers $(\mathrm{O} 3)$ and the least emphasis on the factor of responding rapidly to the threats of competitive actions (O5) and on integrating all business functions in serving the needs of target markets $(\mathrm{O} 7)$.

\section{Conclusion and Recommendation}

This study measured the status of the current practices of market orientation among different categories of GLCs in Malaysia by assessing ten related factors. The factor analysis provided the consistency of these ten variables for market orientation measurement. $86.6 \%$ of the respondents admitted to exercising these ten factors of market orientation, and their average score was 4.1 out of a 5 scale. Therefore, there is scope for improving the practices of market orientation by the GLCs. Hence, the GLCs need to put in extra initiatives to create value so that they will be able to meet the requirements and expectations of the government and at the same time, be able to increase and add value to their products, services and business performance (Lawler and Mohrman, 2013). Overall, GLCs should emphasize on paying close attention to after-sales service, responding rapidly to the threats of competitive actions, regularly discuss the competitors' strengths and strategies by the top management, and freely communicate the successful and unsuccessful customer experiences across all business functions. However, the state owned or federal owned GLCs and GLCs engaged in the manufacturing or service sector should emphasize more on market orientation to exhibit higher level accountability.

\section{Acknowledgement}

We would like to express our sincere gratitude to the Accounting Research Institute (ARI), Universiti Teknologi MARA, Shah Alam, and the School of Economics, Finance \& Banking, College of Business, Universiti Utara Malaysia, Sintok, Kedah in collaboration with the Ministry of Education Malaysia (MOE) in providing financial assistance to carry out this research project. The research was supported under the Fundamental Research Grant Scheme (FRGS).

\section{References}


Arumugam, G. S., Guptan, V., \& Sganmugam, B. (2011). Market Orientation in a GLC: Evidence from Malaysia. Problems and Perspectives in Management.9(2); 51-62.

Barney, J. B. (1991). Firm Resources and Sustained Competitive Advantage. Journal of Management, 17: 99-120.

Boso, N., Story, V. M., \& Cadogan, J. W. (2013). Entrepreneurial orientation, market orientation, network ties, and performance: Study of entrepreneurial firms in a developing economy. Journal of Business Venturing, 28(6), 708-727.

Entebang, H. (2010). Entrepreneurial Orientation and Corporate Entrepreneurship Performance of Government-Linked Companies in Malaysia. Queen's University Belfast, Belfast.

Gholami, S. (2011). Value Creation Model through Corporate Social Responsibility (CSR). International Journal of Business and Management, 6(9): 148-154.

Gupta, N. J., \& Benson, C. C. (2011). Sustainability and Competitive Advantage: An Empirical Study of Value Creation. Competition Forum, 9(1): 121-136.

Khazanah, (2014). GLCs Delivering High Performance and Catalysing Inclusive Growth. Retrieved from http://www.khazanah.com.my/docs/140610\%20GLC\%20Progress\%20Review.pdf

Kraaijenbrink, J., \& Spender, J., C.,. (2011). Theories of the Firm and their Value Creation Assumptions. Annual International Conference of the Strategic Management Society, 69 November, Miami, US.

Lau, Y. W., \& Tong, C. Q. (2008). Are Malaysian Government Linked Companies (GLCs) creating value? International Applied Economics and Management Letters, 1(1):9-12.

Lawler, E. E., \& Mohrman, A. S. (2013). Sustainability: What Should Boards Do? Centre for Effective Organization. CEO Publication (January), Marshall School of Business, University of Southern California.

McLaughlin, H. M. (2002). The Relationship Between Learning Orientation, Market Orientation and Innovation and Their Effect On Organizational Performance. Unpublished doctoral dissertation, Nova Southeastern University,

Porter M.E. (1997). Competitive Strategy, Measuring Business Excellence, 1(2):12-17.

Razak, N. H. A., Ahmad, R, \& Joher, H. A. (2011). Does government linked companies (GLCs) perform better than non-GLCs? Evidence from Malaysian listed companies. Journal of Applied Finance \& Banking, 1(1): 213-240. 